\title{
ANOTHER POEM FOR WALLACE STEVENS
}

You are Isis, and I, a hen

picking among chaff,

move my thin head.

You flow, over rocks

and around reeds,

searching, as Isis

for her child, who will play

again by the sacks

of grain, shadowed in the shadowy barn.

We too, your readers, hollys of darkness,

mistletoes of winter, wait

for the Shining One, with whom

we will flee over the littered and wind blown roads.

\section{WATER RECONCILIATION}

When your privacy is beginning over,

how beautiful the things that you did not notice!

A few sweetclover plants in the ditch along the road to Bellingham,

culvert mouths in driveway approaches,

wooden corncribs, leaning,

what no one loves, no one rushes toward or shouts about,

what lives like the new moon,

and the wind

blowing against the rumps of grazing cows.

Telephone wires stretched across water, the drowning sailor standing at the foot of his mother's bed, grandfathers and grandsons sitting together.

\section{Robert Bly}

\section{$91 \quad$ Criticism}

